\title{
UNDERSTANDING DERADICALIZATION: METHODS, TOOLS AND PROGRAMS FOR COUNTERING VIOLENT EXTREMISM Author: Daniel Koehler \\ Oxon/New York: Routledge, 2016
}

\author{
Marko Krstić \\ Police Directorate in Šabac, Ministry of Interior Affairs, Serbia
}

Daniel Koehler is Director of the German Institute for Radicalization and DeRadicalization Studies (GIRDS) in Berlin. In his book "Understanding Deradicalization: Methods, Tools and Programs for Countering Violent Extremism" (2016), Koehler provides a comprehensive study of different aspects of deradicalization, including the most relevant deradicalization theories, programs, methods and tools.

This book provides insight into the theoretical and practical aspects of radicalization and deradicalization based on an intensive review of existing research in this area, the author's own practical experiences as an advocate for deradicalization, more than 50 interviews with former right-wing extremists, and detailed case studies of reintegration and separation programs around the world. The author classifies these programs into specific typologies and methodologies, and elaborates on the deradicalization concepts, practices, and effects.

The aim of this book is to consolidate the existing knowledge and research fund on the deradicalization process and to improve this field by proposing the deradicalization theory, including instruments for measuring effectiveness, standard methods and procedures, various actors of such programs, and cooperation at the national and international levels. The book enables the readers to discover how the deradicalization programs work, how they can be developed and structured, and how to identify their limitations. However, deradicalization remains a context-related activity and there are solutions that do not fit into one size. Policy makers and practitioners must establish those programs that work best in the given political and legal fields. These locally-adapted models can and should be based on a thorough understanding of the mechanisms of radicalization and deradicalization, as well as on the quality standards that have proved essential in effective programs.

Received January $24^{\text {th }}, 2019 /$ Accepted February $6^{\text {th }}, 2019$

Corresponding author: Marko Krstić, Police Directorate in Šabac, Ministry of Interior Affairs, Republic of Serbia; e-mail: marko.krstic.1982@gmail.com 
Very few topics have recently received more attention than the concept of deradicalization, especially since the September 11 attacks on the World Trade Center and the Pentagon. However, very few studies have provided or comprehensively analyzed such programs in detail, or offered a framework that allows political structures and security authorities to design and effectively implement deradicalization programs in different contexts. In the Introduction, the author states that after September 11 and subsequent terrorist attacks, Western and non-Western countries recognized the need for alternatives to repression and prosecution as means of combating terrorism, violent radicalization and extremism, realizing that it would be impossible to annul the terrorist threat by "bombing" and "arrest". The investigation of numerous subsequent terrorist attacks, such as those in Madrid (March 2004), Amsterdam (November 2004), London (July 2005), Stockholm (December 2010), Brussels (May 2014), and Paris (January and November 2015), has shown that a vast majority of perpetrators were actually born, raised and radicalized in these countries As a consequence, Western governments have tried to introduce various strategies to combat violent extremism (CVE), designed to combat radicalization at the domestic level, observing the experiences and practices in their environments, but also on the basis of promising and highly innovative approaches developed in the Middle East and the Southeast Asian countries. For example, after the US proclaimed "war on terror", many rehabilitation programs were instituted to address an increasing number of prisoners. Religious structures in Yemen, Saudi Arabia, Singapore, Indonesia and Malaysia organized theological debates in an attempt to "deradicalize" prisoners convicted of extremist views.

Koehler raises a number of questions: what is "deradicalization"; how it is implemented, measured and controlled? There are many synonyms for deradicalization, such as: "reintegration", "rehabilitation", "re-education", "removal", "separation", "deprogramming", all of which involve a similar process of transformation from the position of approval and use of violence to the position of abstaining from violence. But this is not a simple process, and experts in this field consider that there is a lack of understanding in different discourses on the impact of deradicalization. It is necessary to understand the dynamics behind the path towards violent radicalism and backward activism. Discussing the situation in radicalization research, the author shows that the basic mechanism behind radicalization can be conceived as a process of "de-pluralization" of political concepts and values, which, combined with a specific ideology, ultimately leads to violence as the only valid course of action.

In response to terrorist attacks, many developed countries have endevoured to provide various programs in the field of deradicization. After the Syrian conflict in 2011, many foreign fighters returned to their countries of origin, which induced the governments to fund and develop counter-radicalization and deradicalization programs. They have supported these programs for two main reasons: first, in many countries, many of these ideologically radicalized individuals could not be prosecuted and convicted for lack of evidence; second, a large number of radicalized and violent individuals could end up in prison and spread their radical ideology there. So, prevention, early intervention and deradicization programs could facilitate the work of security services and help the governments in combating violence, terrorism and extremism.

This book can greatly help practitioners and researchers to better understand the domain of deradicalisation and facilitate their work. It contains instruments and advanced theoretical concepts valuable for fieldwork. Although the struggle against violent extremism and deradicalization is still very controversial in many countries, an attempt to turn individuals and groups back from the path of violence not only protects our societies but also 
contributes to strengthening their basic values and identities. In this way, deradicalization, as an additional tool for combating violence and extremism, helps protect communities, families and societies at large. Fears related to deradicalization are often based on a lack of conceptual clarity, poor training, structural integrity and transparency. Although these instruments are not an effective means of combating terrorism, they still have a significant potential to increase society's resilience and to improve security. The goal of this book is to make this potential visible and accessible to those academics, practitioners and policy makers who see the need for developing such programs.

The book includes eleven chapters and numerous topics. The first two chapters describe the methodological approach in the book and provide the necessary academic background for research and practice of deradicalization and separation programs. The author includes the experiences of people involved in these programs at different levels, as well as their own professional (practical) experience in such initiatives. Chapter 3 provides a discussion on the radicalization process, including the role of ideologies and dynamics activism, which are essential for understanding the deradicalization theory. Chapter 4 discusses various aspects of deradicalization and separation programs, and specific benefits and effects of deradicalization programs on counteracting terrorism. Chapter 5 includes a typology of deradicalization programs with practical examples from all over the world. Chapter 6 discusses the relevant aspects of a highly specilized deradicalization-oriented family counseling, a recenlty developed program for early prevention and intervention. Chapter 7 critically assess the issue of effectiveness of deradicalization programs, which may be particularly useful to readers who want to learn more about designing such programs and evaluating their effects and outcomes. Chapter 8 discusses the moral legitimacy of deradicalization, with reference to the ideological component. Chapter 9 presents important practical for planning, building and mainitaining a deradicalization program, and a core set of tools such as mentoring, vocational training, psychological counceling, and educational methods. Chapter 10 provides detailed descriptions of the existing programs and a useful overview of relevant initiatives from a global perspective. Chapter 11 elaborates on the lessons learned from the study and proposes future reaserach and policymaking directions.

The introduction of deradicalization and separation entails cooperation between several state (security) agencies, prosecutors and public services. It becomes more and more evident that the family also plays a key role in achieving these policy objectives, for example by providing an alternative social environment in relation to the environment provided by extremists.

In discussing the deradicalization and separation programs, Koehler critically assesses the dominant ideologies that are used as weapons for reintegration and rehabilitation into society, and deterrence from further involvement in violent movements. On the other hand, focusing only on "separation" programs and ignoring the ideological aspects of deradicalization, opens an opportunity for criticism. Helping ideologically radicalized people to "liberate" and go back to "normal" law-abiding life, without addressing their radical ideology, could at the same time help potentially dangerous individuals to be more effective in secretly undermining social values that they want to destroy, or continue to support their radical groups, the milieu and the ideological cause even more efficiently. Koehler reassesses and analyzes the programs that focus on helping individuals and groups after leaving a terrorist group and violent radicalism. He critically evaluates the basic ideologies in deradicalization and separation programs that are used as weapons for 
reintegration and rehabilitation into society, and preventing further involvement in violent movements.

On the other hand, the criticism of academicians and practitioners on the process of "securitization" of social programs includes concerns that police, intelligence and even military organizations are slowly destroying the primary success factors of these programs and "soft" approaches by adopting and using them as classical repression tools (e.g. intelligence gathering, identification of dangerous individuals and monitoring). It should be emphasized that the vast majority of these programs around the world are currently the focal point of the police, intelligence or military forces. Although these effects largely depend on many factors (actors, target groups, definitions, work standards, goals), the international academic and political debate about the nature, scope and structure of these programs is still very diverse and controversial.

The author states that one of the most interesting innovations in the last few years in the field of deradicalization programs are specialized deradicalization-oriented family counseling programs aimed at early identification of violent radicalism, including the family and immediate social environment into the deradicalization process, and developing targeted, customized and highly individualized intervention programs. Such family counseling programs, usually in the form of state counseling, have been introduced in various countries around the world since 2012 and they complement the existing counterradicalization policies on several levels.

The "effectiveness" and "success" in deradicalization will naturally remain some of the most controversial terms related to this field. Although the author's believes that deradicalization programs can be highly effective instruments for counteracting terrorism, the evaluation of these programs is fairly sporadic and inadequate at a global level. Practically speaking, almost no (or very few) deradicalization programs have been subject to any scientific evaluation in terms of positive and negative effects. This is inconsistent with almost unanimous assertion that the highest success rates (particularly those related to recidivism after release from prison) are recorded in almost every known deradicalization program in the world. Although the terrorism-related recidivism rates have not been established, some studies suggest that these rates are much lower than the recidivism rates in common crimes. Therefore, the claims on success of deradicalization programs can theoretically be the natural result of the low rates of recidivism in terrorism.

One of the basic lessons learned from this study is that different types of deradicalisation programs have different strengths and weaknesses. Depending on the actors in the specific program (governmental or non-governmental agents), the role of ideology (which may be included or not), and the tupe of approach (active or passive), these different types of deradicalization are essential for understanding the most suitable target groups, risks, practical difficulties, success expectations and actual effects. State programs with counter-ideological approaches, for example, have a naturally higher rate of anticipated failure (abandoning participation and recidivism) than those based on voluntary participation and a more subtle approach to conflicting extremist ideology. In general terms, programs around the world are often a combination of psychological counseling, mentoring, professional development, education and techniques designed to help build self-awareness and positive identities. It is considered essential that programs also provide post-monitoring and aid for economic reintegration, although this aspect is quite limited by available resources and political contexts. 
Another key lesson of this study is that deradicalisation programs, if based on strong quality standards and specialized staff development, can be highly effective instruments against terrorism. Some specific effects in the field of this struggle are, for example, the disruption of group hierarchies, insight into recruitment processes, the availability of strong and credible counter-narratives (through the involvement of former extremists), and creating suspicion about extremist ideologies and militias. However, these effects cannot be generalized and they depend on many factors, such as the type of program, target group and the modus operandi of the specific deradicalization program.

On the whole, it may be concluded the Daniel Koehler provides a unique, coherent and cmprehensive guide to different aspects of radicalization and deradicalization theories, as well as a range of existing deradicalization programs, methods and practical tools that may be employed in planning, developing, implementing and assessing the efficiency of such programs in practice. As it consolidates the existing knowledge and practical experiences in the field, this book may be a valuable resource for practitioners and policymakers who need to build and evaluate such programs at the national and international level, as well as a significant resource for scholars interested in researching the deradicalization programs, methods and procedures. It may also be interesting for students of law and politics, criminology, security studies, counter-terrorism, and international relations.

\section{REFERENCES}

Koehler, Daniel (2016). Understanding Deradicalization: Methods, Tools and Programs for Countering Violent Extremism, 1st ed., Routledge, Taylor and Francis Group, London/New York; available at: https://www.routledge.com/Understanding-Deradicalization-Methods-Tools-and-Programs-forCountering/Koehler-Horgan/p/book/9781138122772; https://www.book2look.com/embed/9781317304388 German Institute on Radicalization and De-radicalization Studies (GIRDS): New Standard on Deradicalization (posted 22.11.2016); http://girds.org/news/new-standard-work-on-deradicalization-published

Proofreading and copy-editing:

Gordana Ignjatović 